\title{
Impact of long-range transport over the Atlantic Ocean on Saharan dust optical and microphysical properties based on AERONET data
}

\author{
Cristian Velasco-Merino ${ }^{1}$, David Mateos ${ }^{1}$, Carlos Toledano ${ }^{1}$, Joseph M. Prospero ${ }^{2}$, Jack Molinie ${ }^{3}$, \\ Lovely Euphrasie-Clotilde ${ }^{3}$, Ramiro González ${ }^{1}$, Victoria E. Cachorro ${ }^{1}$, Abel Calle ${ }^{1}$, and Angel M. de Frutos ${ }^{1}$ \\ ${ }^{1}$ Grupo de Óptica Atmosférica, Dpto. de Física Teórica Atómica y Óptica, Universidad de Valladolid, Valladolid, Spain \\ ${ }^{2}$ Cooperative Institute for Marine and Atmospheric Studies, Rosenstiel School of Marine and Atmospheric Science, \\ University of Miami, Miami, Florida, USA \\ ${ }^{3}$ Laboratory of Geosciences and Energy, Université des Antilles, Pointe-à-Pitre, Guadeloupe, France
}

Correspondence: Carlos Toledano (toledano@goa.uva.es)

Received: 23 November 2017 - Discussion started: 20 December 2017

Revised: 24 May 2018 - Accepted: 10 June 2018 - Published: 5 July 2018

\begin{abstract}
Arid regions are a major source of mineral dust aerosol. Transport from these sources can have a great impact on aerosol climatology in distant regions. In order to assess the impact of dust on climate we must understand how dust properties change after long distance transport from sources. This study addresses the changes in columnar aerosol properties when mineral dust outbreaks from western Africa arrive over the eastern Caribbean after transport across the Atlantic Ocean, a transit of 5-7 days. We use data from the NASA Aerosol Robotic Network (AERONET) located at five Caribbean and two western Africa sites to characterize changes in columnar aerosol properties: aerosol optical depth (AOD), size distribution, single scattering albedo, and refractive indexes. We first characterized the local aerosol climatology at each site and then using air mass back trajectories we identified those days when trajectories over Caribbean sites back-tracked to western Africa. Over the period 1996-2014 we identify 3174 days, an average of 167 days per year, when the air mass over the Caribbean sites could be linked to at least one of the two western Africa sites. For 1162 of these days, AOD data are available for the Caribbean sites as well as for the corresponding western Africa sites about 5-7 days earlier, when the air mass passed over these sites. We identified dust outbreaks as those air masses yielding AOD $\geq 0.2$ and an Angström exponent below 0.6. On this basis of the total 1162 days, 484 meet the criteria for mineral dust outbreaks. We observe that the AOD at $440 \mathrm{~nm}$ decreases by about 0.16 or $30 \%$ during transport. The volume particle size distribution shows a similar decrease in the volume con-
\end{abstract}

centration, mainly in the coarse mode. The single scattering albedo, refractive indexes, and asymmetry factor remain unchanged. The difference in the effective radius over western Africa sites with respect to Caribbean sites ranges between 0 and $-0.3 \mu \mathrm{m}$. Finally we conclude that in about half of the cases only non-spherical dust particles are present in the atmosphere over the western Africa and Caribbean sites, while in the other cases dust particles were mixed with other types of aerosol particles.

\section{Introduction}

Mineral dust is one of the most abundant aerosol types in the global atmosphere and as such it could play an important role in climate. Mineral dust absorbs and scatters terrestrial and solar radiation and thus affects the Earth's radiation budget (Choobari et al., 2014). Dust is also involved in cloud microphysical processes which in turn affect radiation properties and the hydrological cycle (Karydis et al., 2017; DeMott et al., 2010). Dust also serves as a major source of nutrients for ocean and terrestrial ecosystems and in this way dust deposition can impact the carbon cycle (Jickells et al., 2005). All these processes could have a significant impact on climate. Given the importance of dust there is a need to understand the factors affecting African dust source activity, the properties of the dust so produced, and how those properties change during transport. Africa is the world's largest dust source, estimated to produce over half the global total (Huneeus et 
al., 2011). Much African dust is transported to the west and significant quantities reach South America (Prospero et al., 2014; Yu et al., 2014, 2015), the Caribbean Sea (Prospero and Lamb, 2003), and southern United States (Bozlaker et al., 2013).

Studies of the dust transport from Africa to the Americas have been carried out using meteorological information linked to in situ and satellite aerosol data (e.g., Jickells et al., 2005; Rodríguez et al., 2015; García et al., 2017). Recently developed techniques such as MACC (Monitoring Atmospheric Composition and Climate; Chouza et al., 2016) or MOCAGE (Modélisation de la Chimie Atmosphérique Grande Echelle; Martet et al., 2009) models have been also used to monitor dust plumes.

Long-term (e.g., Prospero and Lamb, 2003; Prospero and Mayol-Bracero, 2013) and short-term (e.g., Reid et al., 2003; Colarco et al., 2003; Kaufman et al., 2005; Valle-Díaz et al., 2016) studies show a seasonal dependence in the intensity of dust transport to the Caribbean with the greatest transport in boreal summer. In the SALTRACE program (Weinzierl et al., 2017) an aircraft was used to carry out atmospheric column closure experiments performed in June and July 2013 at western Africa and Caribbean sites. A unique Lagrangian in situ study was carried out in SALTRACE wherein a dusty air mass was sampled aboard an aircraft over the islands of Cabo Verde and again 5 days later over Barbados, a distance of more than $4000 \mathrm{~km}$. They measured a distinct change in particle size during transit across the Atlantic and noted that the removal rate of large super-micron particles was slower than expected based on simple sedimentation calculations (Weinzierl et al., 2017). Similar results had been obtained on comparisons between surface based measurements at sites in the Canary Islands and Puerto Rico (Maring et al., 2003).

Our study is inspired by that experiment, although our approach is to use columnar aerosol data collected from CIMEL sun photometers of the AERosol RObotic NETwork (AERONET) in two areas, western Africa and on islands in the eastern Caribbean. The temporal coverage of the AERONET data is large in both regions, 19 years from 1996 to 2014. Therefore, the aim of this work is to investigate the changes in dust optical and microphysical properties due to the long-range transport, by comparing AERONET observations in western Africa and the Caribbean sites using a climatological approach.

In Sect. 2 we present an overview of the database and methodology used to match daily averaged AERONET data at both sides of the Atlantic Ocean using air mass backwards trajectories. Section 3 describes, separately, the longterm aerosol climatology observed at the western Africa and the Caribbean sites and the correlation between aerosol optical depth (AOD) and dust concentration observed at the Caribbean sites. Section 4 presents the monthly variability of size-related aerosol parameters. Section 5 presents the seasonality of African-Caribbean Sea air mass connections, as well as the change in aerosol optical depth, size distribu- tion, and single scattering albedo, among others after the long-range transport. Finally the conclusions are presented in Sect. 6.

\section{Database and methodology}

\subsection{AERONET measurements and sites}

The main database for this study includes the daily mean values of columnar aerosol data measured by CIMEL CE318 Sun photometer in the AERONET framework (Holben et al., 1998). The direct sun algorithm provides a database that contains instantaneous values (every $15 \mathrm{~min}$ ) of spectral AOD at 7 wavelengths in the range 340$1020 \mathrm{~nm}$ (in some cases also $1640 \mathrm{~nm}$ depending on the instrument model) and the associated Angström exponent (AE) based on the wavelengths 440 and $870 \mathrm{~nm}$. We only use AOD and AE quality-assured cloud-screened level 2.0 data (version 2) which ensures the reliability of the measurements (see http://aeronet.gsfc.nasa.gov/new_web/PDF/ AERONETcriteria_final1.pdf; last access: 18 June 2018). In this work we use only the $440 \mathrm{~nm}$ measurements. Figure 1 and Table 1 present the five AERONET sites in the Caribbean (CAR) area and the two sites in the western Africa (AF) region chosen in this study.

In addition the CIMEL instrument takes hourly measurements of sky radiances in almucantar geometry at certain wavelengths in the range 440-1020 nm (in some cases also $1640 \mathrm{~nm}$; number of wavelengths depends on the instrument model). The sky radiances, together with the AOD, are used to derive optical and microphysical properties of the aerosol using inversion procedures (Dubovik et al., 2006). The inversion-derived parameters used in this study are volume particle size distribution $(\mathrm{d} V(r) / \mathrm{d} \ln (r)$; VPSD) and the volume concentration for the fine, coarse, and total size distribution $\left(\mathrm{VC}_{\mathrm{F}}, \mathrm{VC}_{\mathrm{C}}, \mathrm{VC}_{\mathrm{T}}\right.$, respectively), sphericity fraction $(\mathrm{SF})$, total effective radius $\left(\mathrm{ER}_{\mathrm{T}}\right)$, real part of the refractive index (REFR), imaginary part of the refractive index (REFI), single scattering albedo (SSA), and asymmetry parameter $(g)$.

The Level 2 inversion requirement rejects AOD values less than 0.4 which dramatically reduces the amount of data. In order to increase the number of measurements in the data set we used level 1.5 inversion products but we applied an extra level of quality control to ensure the reliability of the inversion data:

- VPSD and ER ${ }_{\mathrm{T}}$ : same as AERONET level 2.0 criteria (solar zenith angle $>50^{\circ}$, number of symmetrical angles, and sky error between 5 and $8 \%$ depending on AOD; see above), but without threshold with respect to AOD.

- SSA, $g$, REFR, REFI, and SF: same as AERONET level 2.0 criteria but with $\mathrm{AOD} \geq 0.20$ (see Dubovik et 

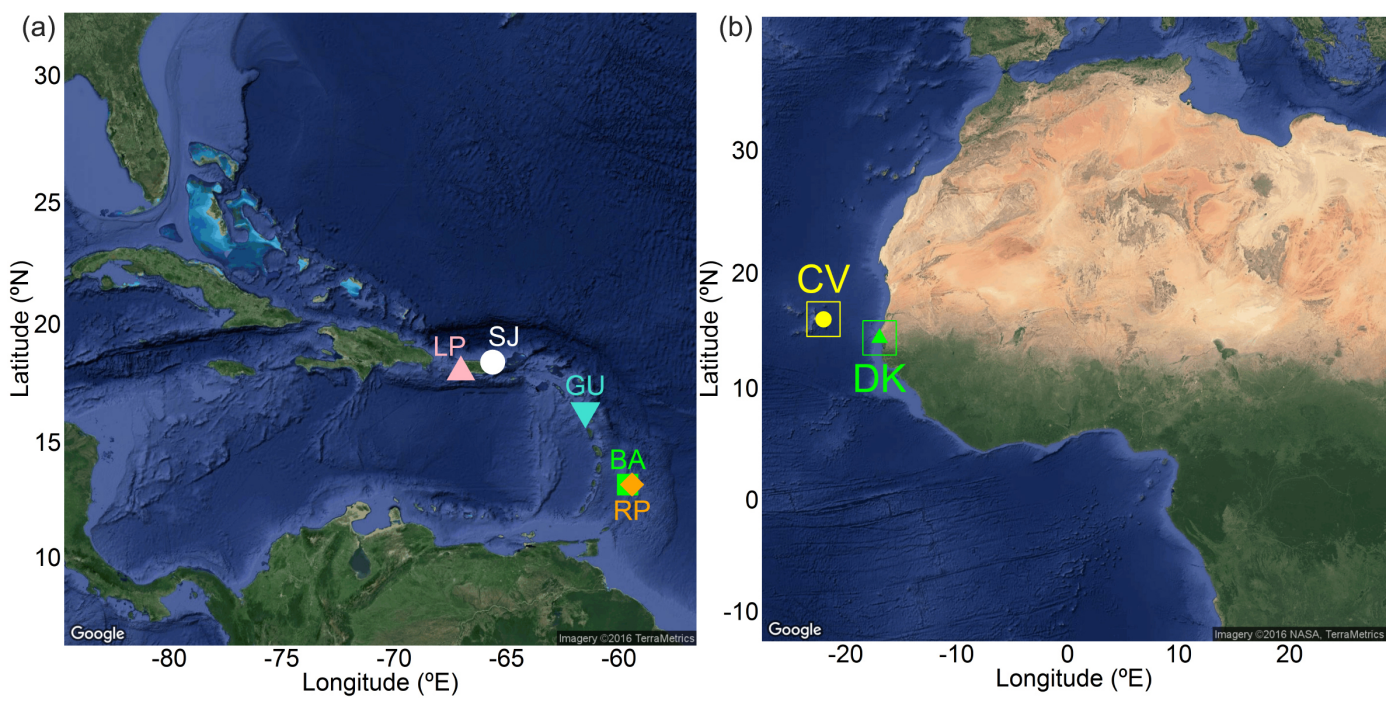

Figure 1. AERONET sites in the Caribbean area (a) and western Africa region (b). For acronyms see Table 1.

Table 1. Geographical coordinates, considered time period, and total number of level 2.0 AOD daily data from the different AERONET sites used for the global African and Caribbean databases. To highlight the number of available inversion products, the number of daily data of volume particle size distribution (VPSD) is presented.

\begin{tabular}{lllll}
\hline Area & Site & $\begin{array}{l}\text { Coordinates } \\
\left({ }^{\circ} \mathrm{N},{ }^{\circ} \mathrm{E}, \mathrm{m} \text { a.s.1. }\right)\end{array}$ & Time period & $\begin{array}{l}\text { Number of AOD/ } \\
\text { VPSD daily data }\end{array}$ \\
\hline AF & Capo_Verde (CV) & $(16.71,-22.93,60)$ & $1993-2014$ & $4635 / 1910$ \\
& Dakar (DK) & $(14.38,-16.95,0)$ & $1996-2014$ & $3593 / 2466$ \\
\hline CAR & Barbados (BA) & $(13.15,-59.62,114)$ & $1996-2000$ & $938 / 50$ \\
& Barbados_SALTRACE (BA) & $(13.15,-59.62,114)$ & $2013-2014$ & $181 / 7$ \\
& Ragged_Point (RG) & $(13.15,-59.42,40)$ & $2007-2014$ & $1768 / 415$ \\
& Guadeloup (GU) & $(16.22,-61.53,39)$ & $1997-2014$ & $1949 / 441$ \\
& La_Parguera (LP) & $(17.97,-67.03,12)$ & $2000-2014$ & $3303 / 1467$ \\
& Cape_San_Juan (SJ) & $(18.38,-65.62,15)$ & $2004-2014$ & $1901 / 401$ \\
\hline
\end{tabular}

al., 2006; Mallet et al., 2013; Mateos et al., 2014) instead of $>0.4$.

The use of level 1.5 filtered data with an extra quality control has been previously used by other authors (e.g., Burgos et al., 2016) with minor loss of accuracy (Mateos et al., 2014). All the available inversion products are daily averaged in this study. With the threshold of AOD $\geq 0.2$, estimated uncertainty for dust retrievals of the single scattering albedo is 0.03 , REFR is 0.04 , REFI is $50 \%$, and the VPSD is $35 \%$ (see Dubovik et al., 2000). The climatology of key aerosol properties measured at western Africa and Caribbean sites is addressed in Sect. 3. All daily available records (see Table 1) at the two western Africa and five Caribbean sites are averaged in the 1996-2014 period, resulting in two databases with 5656 and 5099 days of data, respectively.

\subsection{Linkage between Caribbean and western Africa by air mass back trajectories}

All the air mass links between western Africa and Caribbean sites are examined. This task requires separate analysis for each Caribbean site. For example, the methodology used in this study for Barbados is the following:

- Step 1: We calculated three-dimensional 10-day back trajectories with $1 \mathrm{~h}$ time resolution using the Hybrid Single Particle Lagrangian Integrated Trajectory (HYSPLIT) model version 4.0 (Stein et al., 2015). The geographical coordinates used as the start point for Barbados are presented in Table 1. As mineral dust can be transported at altitude levels higher than the boundary layer, most notably in the Saharan Air Layer (SAL; Carlson and Prospero, 1972; Yu et al., 2014; Groß et al., 2016), back trajectories were calculated at 750, 2500 and $4500 \mathrm{~m}$ (a.g.1.). The core of the SAL is typically 
at around $2500 \mathrm{~m}$. For the trajectory vertical motion, we used the model vertical velocity. The meteorological database used as input for HYSPLIT is the global NCAR/NCEP Reanalysis (Kalnay et al., 1996). The evaluation is performed for each day in the period 19962014 at 16:00 UTC (around local noon).

- Step 2: If any of these trajectories for Barbados (at one, two or three heights) passes through a $3^{\circ} \times 3^{\circ}$ box centered on the western Africa sites, we consider that a link has been established between the two sites. The transit time is typically about 5-7 days. In some cases an air mass back trajectory may link both the Capo_Verde and Dakar boxes. In such cases the mean of the aerosol observations is used.

- Step 3: Once the dates in which the air mass is measured in Barbados and in Capo_Verde or Dakar (or both) sites are established, the associated AERONET aerosol data are identified. In the case of Barbados site, the corresponding daily means of all AERONET products are used. However, the western Africa site analysis requires a special procedure. The visual inspection of many of the cases shows that the aerosol records for the specific date obtained in the trajectory analysis often fell on a day without data (e.g., due to cloudy or rainy conditions) or did not capture the central days of the dust event. To resolve this problem, we introduced a \pm 1 day adjustment to the back-trajectory-estimated date at Capo_Verde and Dakar. This is in line with previous studies which state that desert dust episodes in western Africa sites usually last for several days (e.g., Knippertz and Stuut, 2014). The aerosol values for each western Africa site are therefore averaged over the 3 days (the estimated date and \pm 1 day). For the Barbados-African cases with air masses overflowing both Capo_Verde and Dakar sites, the corresponding average of aerosol data is used.

These three steps described above are applied to all Caribbean sites as shown in Table 1. This methodology yields five databases (one per site) in which each Caribbean site is linked with data for western Africa sites. For each day between 1996 and 2014 we determine which Caribbean sites present an air mass link with western Africa sites. If more than one western Africa site yields a link for a specific Caribbean event, we use the mean properties as discussed above.

We identify a desert dust event on the basis of the following criteria: $\mathrm{AOD} \geq 0.2$ and $\mathrm{AE} \leq 0.6$ (e.g., Dubovik et al., 2002; Guirado et al., 2014). In the evaluated global Caribbean-African linked database, the Caribbean and African data are analyzed separately. Hence, there are two different inventories that contain all days meeting the criteria for mineral dust events over the Caribbean and western

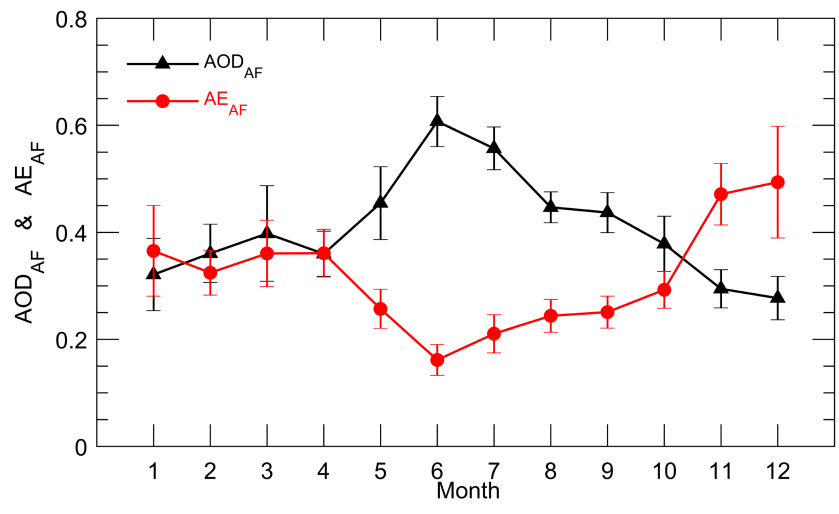

Figure 2. Monthly average of AOD and AE from 1996 to 2014 in the western Africa area. The number of daily means used in the multi-annual averages is 5656 .

Africa sites. In the global database there are, therefore, three different cases which are extensively analyzed in Sect. 5:

a. $D_{\mathrm{AF}}+D_{\mathrm{CAR}}:$ desert dust conditions occur in both Caribbean and western Africa sites;

b. $D_{\mathrm{AF}}+\mathrm{NoD}_{\mathrm{CAR}}$ : dust conditions in western Africa sites but no-dust condition at the Caribbean sites;

c. NoD: no-dust conditions or dust conditions at the Caribbean sites with unproven origin.

We found a total of 3174 days with connections between western Africa and Caribbean sites. Only 1162 out of 3174 days yielded AERONET data (level 2.0) for AOD and AE. Of these 1162 acceptable days, 484 meet the criteria for mineral dust outbreaks $(\mathrm{AOD} \geq 0.2$ and $\mathrm{AE} \leq 0.6$, " $D_{\mathrm{AF}}+D_{\mathrm{CAR}}$ " case). However for the analysis of microphysical and radiative properties, the number of matching inversion data is much smaller (just 71 cases) because of the more stringent requirements. The frequent cloudiness at the Caribbean sites is the main difficulty in the inversion of sky radiances (see Table 1).

\section{Seasonal variability of aerosol load at the western Africa and Caribbean sites}

In this section the analysis of the monthly seasonal cycle of the main aerosol properties at the Caribbean and western Africa sites is presented separately since there is no requirement that trajectories connect the sites. This section summarizes overall multi-year statistics (from 1996 to 2014) of AOD, AE, and VPSD quantities.

Figures 2 and 3 present the multiannual AOD and AE monthly averages of 19 years in western Africa and Caribbean regions, respectively. There is a significant difference between the "cold" (October-April) and "warm" (MaySeptember) seasons in both areas. 


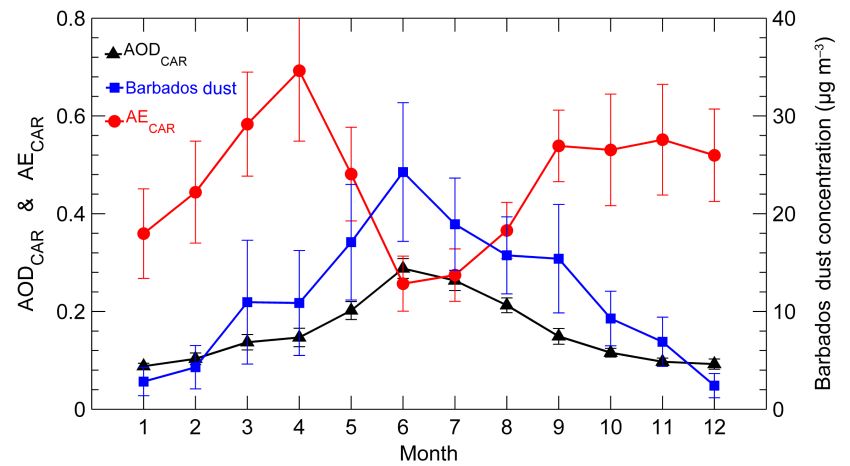

Figure 3. Monthly average of AOD and $\mathrm{AE}$ in the Caribbean area from 1996 to 2014 and surface dust concentrations in Barbados in the period 1996-2011. The number of daily means used in the multi-annual averages is 5099 for $\mathrm{AOD}_{\mathrm{CAR}}$ and $\mathrm{AE}_{\mathrm{CAR}}$ and 5167 for surface dust concentration in Barbados.

In the winter season there is a weak variation of AOD and $\mathrm{AE}$ at the western Africa sites (see Fig. 2) with values around 0.3 and $0.3-0.5$, respectively. In contrast in the summer season there is an increase of AOD together with a decrease of AE until June when the maximum of AOD (0.6) coincides with a minimum of AE (0.16). The AOD peak was also observed by, e.g., Tegen et al. (2013). After June there is a progressive decrease of AOD values and increase in $\mathrm{AE}$ until once again reaching winter levels. Overall, the large AOD and low $\mathrm{AE}$ values suggest dominant effect of coarse particles in dust episodes. The ranges of AOD between 0.3 and 0.6 and $\mathrm{AE}$ below 0.5 were also obtained by previous studies in western Africa sites (e.g., Dubovik et al., 2002; Horowitz et al., 2017). Haywood et al. (2008), Derimian et al. (2008), and Leon et al. (2009) reported that M'Bour site (western Senegal, $70 \mathrm{~km}$ away from Dakar) is strongly influenced by desert dust throughout the year. The effects of biomass burning are seen in November and December when AE reaches its maximum of about 0.5 ; this is the time of year when biomass burning is at a maximum in the Sahel.

The annual cycle of AOD at the Caribbean sites (see Fig. 3) shows a bell shape with the maximum in June $(\mathrm{AOD}=0.3)$ and the minimum values in December-January. In contrast, the $\mathrm{AE}$ displays a larger variability along the year: an increase from January to April when $\mathrm{AE}=0.7$ (the annual maximum), followed by a steady sharp decline until the absolute minimum in June-July with $\mathrm{AE}=0.26$. Levels remain constant around 0.55 from September to December. These features in the AOD and AE seasonality can be understood as the fingerprint of the occurrence of mineral dust transport from Africa. The AE variability evidenced by the standard deviations is largely driven by the changes in aerosol mixture that occur in this area (e.g., Reid et al., 2003). Clean maritime conditions, associated with background values, have low AOD and low AE (Smirnov et al., 2000), but they can be modified by mineral dust outbreaks from African deserts and biomass burning episodes. In particular, the large change in AE in the cold season is largely due to the advection of pollutant aerosols from higher latitudes (e.g, Savoie et al., 2002; Zamora et al. 2013).

Previous work (e.g., Smirnov et al., 2000) has shown that high concentrations of dust at the surface are correlated with high column optical depths measured by a collocated AERONET instrument. Yu et al. (2014) has shown that CALIPSO (Cloud-Aerosol Lidar and Infrared Pathfinder Satellite Observations) dust concentrations over Barbados track the surface-based measurements of dust. In Fig. 3 we show the relationship between the long-term measurements of dust concentrations at the surface with the columnar aerosol load manifested in AOD. We use the surface dust concentration measured at the Ragged Point site, Barbados (e.g., Prospero and Lamb, 2003; Prospero and Mayol, 2013) between 1996 and 2011. Daily surface dust concentrations are obtained with high-volume filter samplers using measured aluminum concentrations and assuming an $\mathrm{Al}$ content of $8 \%$ in soil dust (e.g., Prospero, 1999) or from the weights of filter samples ashed at $500^{\circ} \mathrm{C}$ after extracting soluble components with water (Prospero, 1999; Prospero et al., 2014; Savoie et al., 2002).

Surface dust concentration seasonal cycle (Fig. 3) presents a significant increase between low values during OctoberApril season up to larger concentrations in May-September season. Overall, the shapes of the annual cycles of AOD and surface dust concentration at Barbados are similar and the same seasonal pattern in both variables is observed.

Monthly mean AOD is highly correlated with surface dust concentrations as shown in Fig. 4 which is based on 3700 pairs of daily data, a total of 192 monthly mean values, and 12 interannual monthly mean values, the latter calculated as the average of the available daily data from the same month over a multi-annual period. The seasonal distribution of the surface-columnar values seems to follow a linear increasing pattern from winter (bluish colors) to summer (reddish colors). The slope of the fit between dust concentration and AOD is about $115 \mu \mathrm{g} \mathrm{m}^{-3}$ per unit of AOD for the two cases analyzed here: using 192 monthly means (Fig. 4a) and 12 interannual monthly means (Fig. 4b). The Barbados dust concentration vs. AOD shows very good correlation when the same months are averaged along the years. However, the monthly agreement between these two variables displays a certain degree of dispersion with a moderate correlation coefficient. The positive intercepts on AOD in the fits are most likely attributable to the effects of sea salt aerosol on AOD.

\section{Monthly variability of size-related aerosol parameters}

Figure 5 displays the average monthly cycle of the volume particle size distribution (VPSD) for the western Africa and Caribbean sites, respectively. These figures are based on 


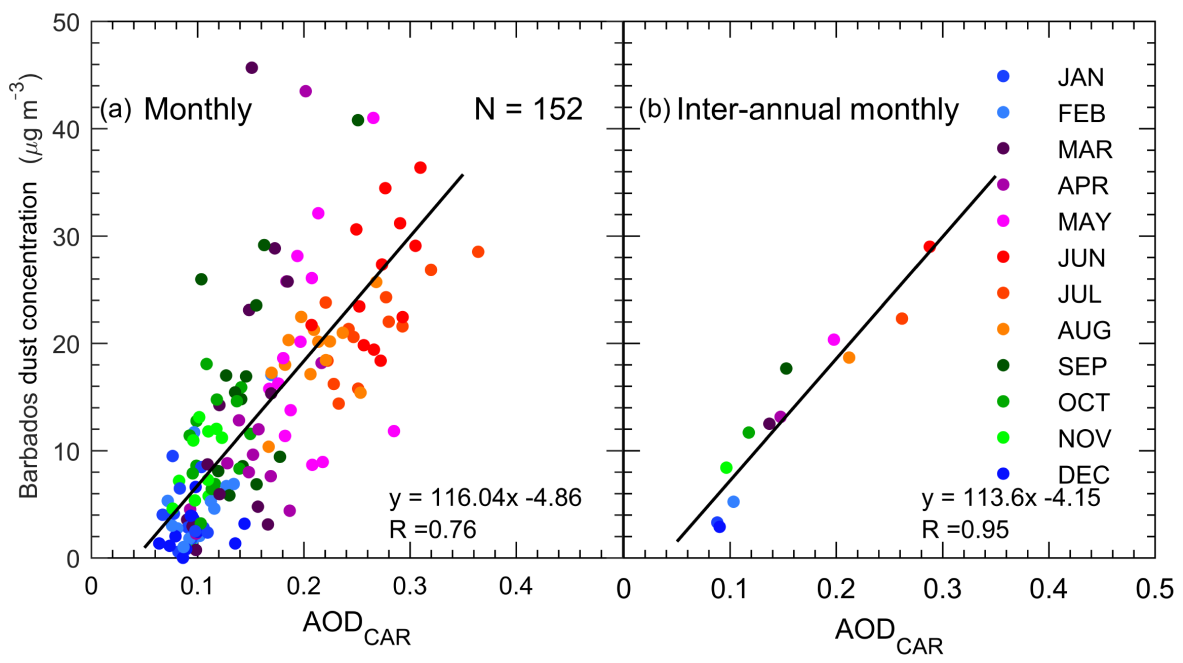

Figure 4. Scatter plot of (a) monthly and (b) interannual monthly means of surface dust concentration and AOD in the Caribbean Basin in the period 1996-2011. Solid line indicates the linear fit between both quantities and $R$ indicates the correlation coefficient.
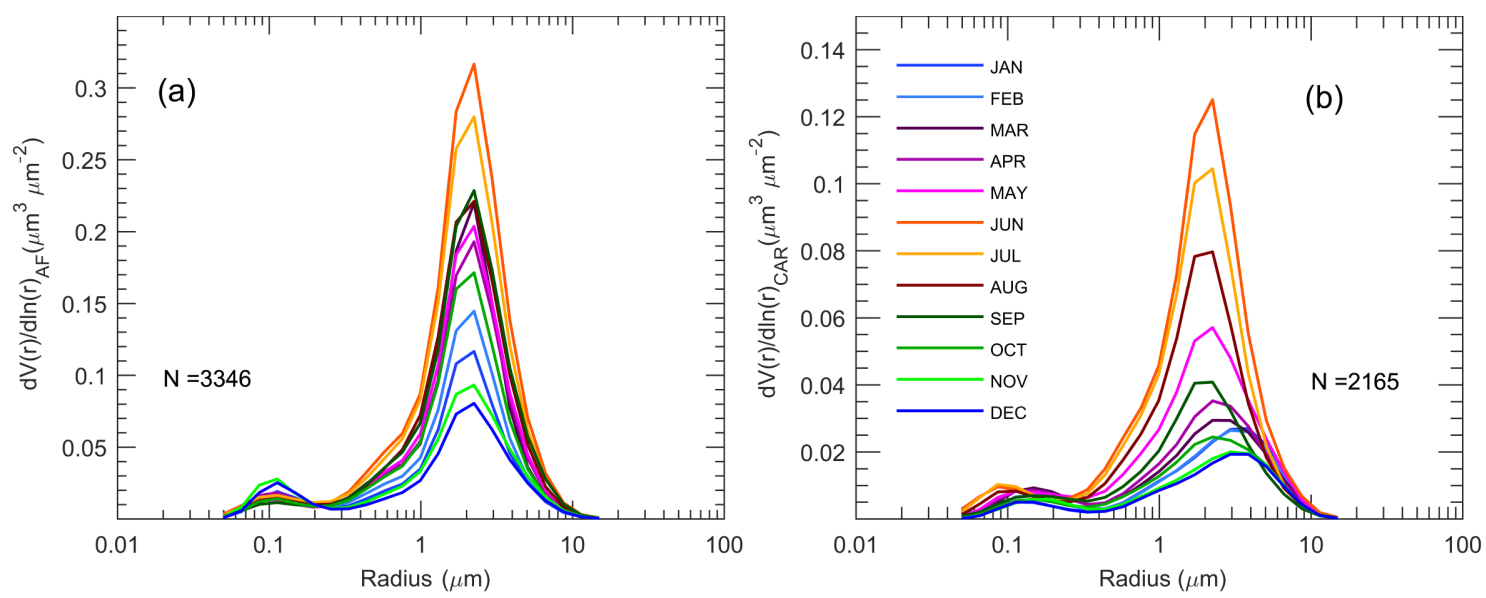

Figure 5. Monthly averages of the volume particle size distribution $(\mathrm{d} V(r) / \mathrm{d} \ln (r))$ from 1996-2014 in western Africa (a) and Caribbean (b) areas.

3346 and 2165 daily mean values of the AERONET inversion products selected as described above.

The coarse-mode predominance can be observed throughout the year in both areas. The seasonal cycle of VPSD in western Africa sites (Fig. 5a) shows a clear change of coarsemode concentration throughout the year, although the coarsemode effective radius does not change, with peak concentration of about $2 \mu \mathrm{m}$. The coarse-mode concentration ranges between maximum values in June with $0.32 \mu \mathrm{m}^{3} \mu \mathrm{m}^{-2}$ and minima in November-December with $0.05 \mu \mathrm{m}^{3} \mu \mathrm{m}^{-2}$. In terms of volume concentration the fine mode plays an almost negligible role throughout the year for the $D_{\mathrm{AF}}+D_{\mathrm{CAR}}$ cases. This seasonal pattern was already reported by previous studies at the western Africa sites (e.g., Dubovik et al., 2002; Eck et al., 2010; Guirado et al., 2014). These studies showed the domination of large particles (i.e., radius greater than $0.6 \mu \mathrm{m}$ ) with VPSD peaks in the coarse mode at $2 \mu \mathrm{m}$, which are independent of the aerosol load.

The conditions observed at the Caribbean sites (Fig. 5b) show a change in the mean size of the aerosol particles during the course of the year. In the warm season (May-September) the maximum concentration peaks of about $2 \mu \mathrm{m}$ radius identical to the coarse-mode size distribution found at the western Africa sites (Fig. 5a), although the concentration values are lower (as is AOD). In the cold season (October-April), however, the coarse-mode maximum concentration is shifted to larger radii $(>3 \mu \mathrm{m})$ highlighting the predominance of large sea salt particles. This difference in the coarse-mode radii between marine aerosol and dust has been observed in other coastal locations affected by dust outbreaks (e.g., Prats et al., 2011). In addition, the maximum volume concentration of the coarse-mode exhibits maximum values in June with 


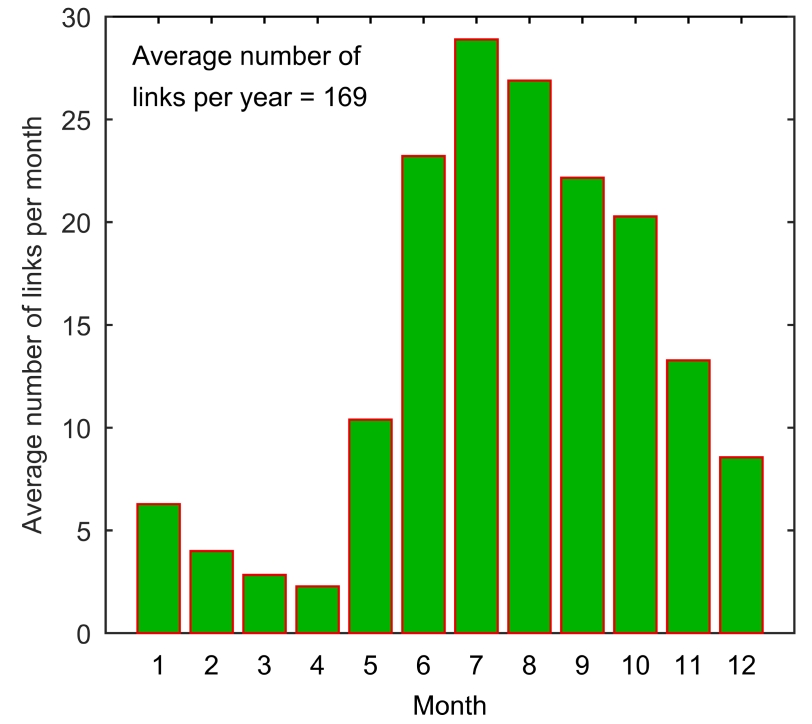

Figure 6. Seasonal cycle of number of African-Caribbean Sea air mass connections. The number of air mass links is 169 per year, with a total of 3174 links in the 19-year period analyzed.

$0.12 \mu \mathrm{m}^{3} \mu \mathrm{m}^{-2}$ and minimum ones in November-December with $0.02 \mu \mathrm{m}^{3} \mu \mathrm{m}^{-2}$. In terms of volume concentration the fine mode plays a minor role throughout the year at the Caribbean sites. The entire size range of VPSD in the cold season is in line with previous studies carried out in oceanic environments (e.g., Dubovik et al., 2002) with low particle volume concentrations peaking at very large radius $(>3 \mu \mathrm{m})$.

\section{Air mass connections between western Africa and Caribbean areas}

In this section, we select only those days when the back trajectories link western Africa sites with Caribbean sites as explained in Sec. 2.2. In this way, the aerosol properties observed at the Caribbean sites can be compared those observed 5-7 days earlier over the western Africa sites.

\subsection{Overview over air mass connections}

Following the methodology described in steps 1 and 2 of Sect. 2.2, we obtained a list of days when Caribbean air masses could be linked to western Africa. Figure 6 shows the seasonal cycle of the total number of days with this connection in the period 1996-2014. Overall, almost half of the days each year ( $\sim 167$ days per year) display a CaribbeanAfrican linkage with a total of 3174 cases in 19 years.

The total number of air mass connections between both areas exhibits small values from January through April with an absolute minimum in April of only 2 days per month. This minimum at the Caribbean sites coincides with the minimum in aerosol load observed in the seasonal cycle at the western Africa sites (see Fig. 2).

With the beginning of the warm season (May-September) the number of connections shows a notable increase achieving its maximum in July with almost all the days at the Caribbean sites being connected with those in western Africa. From October to December there is a progressive decline in links from 20 to 10 days per month.

Unfortunately, columnar aerosol data are not available for all of the 3174 connection days. A total of 1162 out of 3174 days ( $36 \%$ of the total) are present in AERONET AOD and AE data of level 2.0 (see Sect. 2.1). Furthermore, only 484 cases (15\% of the total) meet the dusty criteria in both areas $\left(D_{\mathrm{AF}}+D_{\mathrm{CAR}}\right.$ case described in Sect. 2.2). This is due to the limitation in the data coverage and to the strict criteria used to unambiguously identify desert dust events. It should be noted that this procedure underestimates the actual number of desert dust events observed by ground-based measurements. For instance, during June-July-August at the Caribbean sites there is essentially continuous dust (e.g., Prospero et al., 2014), which is corroborated in this study with an average of 23-28 connection days in these months.

\subsection{Scatter plot of AE-AOD in the western Africa and Caribbean areas}

The next step focuses on the comparison of the aerosol properties observed at the Caribbean sites and the values of the same properties which were observed 5-7 days earlier over the western Africa sites. In this way, the impact of the longrange transport can be quantified. Figure 7 presents the scatter plot of AE-AOD for those days with aerosol data and air mass links between the two areas. When the criteria for identifying mineral dust $(\mathrm{AOD} \geq 0.2$ and $\mathrm{AE} \leq 0.6)$ are applied to the global Caribbean-African connected database, three different cases are identified (see Sect. 2.2).

At the western Africa sites (Fig. 7a), as expected because of the proximity to the Saharan Desert, the influence of the mineral dust aerosol properties is predominant: $86 \%$ of the available data have $\mathrm{AOD} \geq 0.2$ and $\mathrm{AE} \leq 0.6,(1000$ out of 1162 days). We identified the occurrence of 498 dusty days at the Caribbean sites, about $42 \%$ of the entire global Caribbean-African connected database, but just 484 days (in the period 1996-2014) are shown to be dusty days at the Caribbean sites with aerosol origin in the Saharan desert (indicated as a $D_{\mathrm{AF}}+D_{\mathrm{CAR}}$ case in Fig. 7). Intense dusty days (AOD larger than 0.5) occur in western Africa and Caribbean sites in 430 and 67 cases, respectively. This difference is attributable to a decrease in aerosol load during transport between the two regions. Out of the total of 1162 cases 516 meet the dusty criteria only in the African database $\left(D_{\mathrm{AF}}+\mathrm{NoD}_{\mathrm{CAR}}\right.$ case in Fig. 7). This decrease in dust loads is also observed in the change of the $\mathrm{AE}$ and AOD using ground-based and satellite measurements (see, e.g., Yu et al., 2014). For instance, there are 102 cases in the Caribbean 

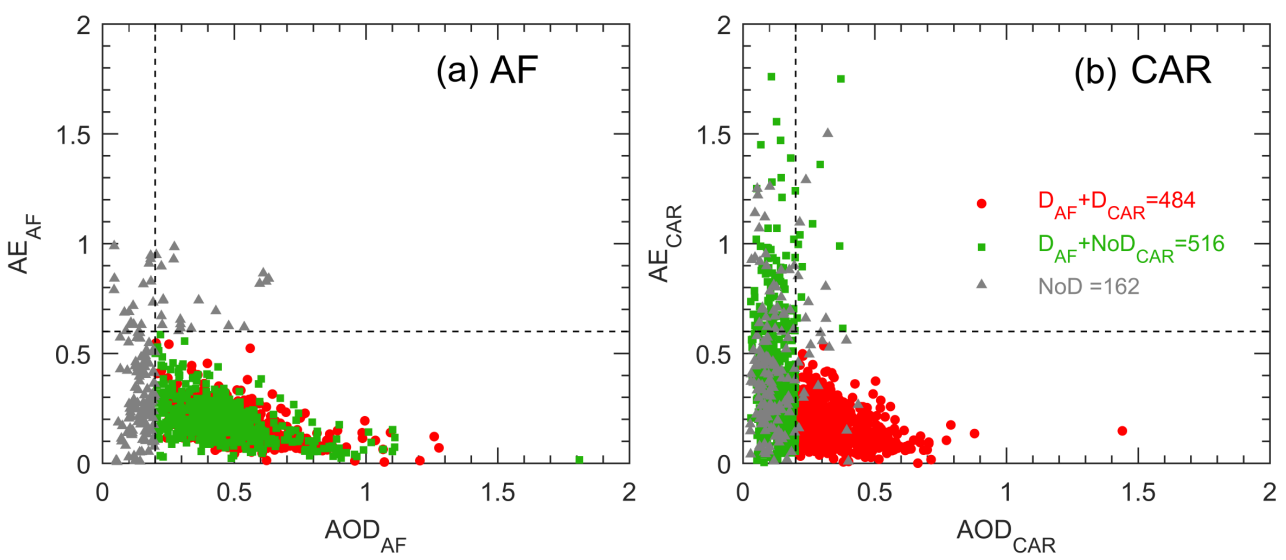

Figure 7. AE-AOD scatter plot for all data days in (a) western Africa and (b) Caribbean Sea. Red circles are dust days in both Africa $\left(D_{\mathrm{AF}}\right)$ and Caribbean $\left(D_{\mathrm{CAR}}\right)$ databases, green squares are dust days in western Africa that are not dusty in Caribbean area $\left(\mathrm{NoD}_{\mathrm{CAR}}\right)$, and grey triangles are non-dusty days ("NoD"). Dashed lines indicate the criteria for identifying mineral dust (AOD $\geq 0.2$ and AE $\leq 0.6)$. See text in Sect. 2.2 .

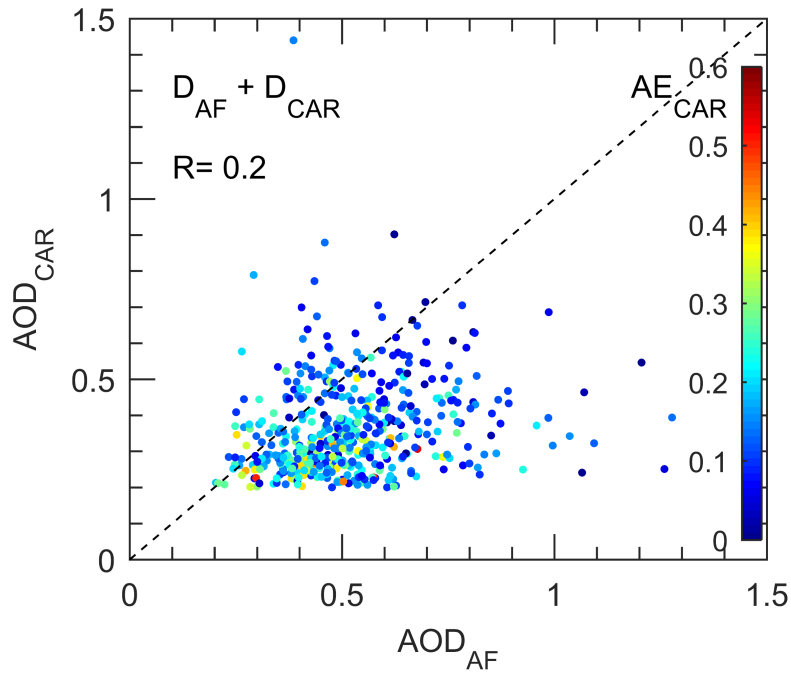

Figure 8. Scatter plot of AOD in the Caribbean ( $\left.A_{C D} D_{C A R}\right)$ versus $\mathrm{AOD}$ in the western Africa region $\left(\mathrm{AOD}_{\mathrm{AF}}\right)$ when dust is observed in both areas $\left(D_{\mathrm{AF}}+D_{\mathrm{CAR}}\right.$ case; see Sect. 2.2). The color scale indicates the $\mathrm{AE}$ in the Caribbean area $\left(\mathrm{AE}_{\mathrm{CAR}}\right)$. Dashed line indicates no change in AOD between both areas, and $R$ indicates the correlation coefficient.

database where $\mathrm{AE}>0.6$, whereas the same air mass yielded $\mathrm{AE}<0.6$ at the western Africa sites days before. Probably there are days with presence of dust with AOD and AE values close to the required thresholds ( 156 and 59 days in the interval of $0.15<\mathrm{AOD}<0.20$ at the Caribbean and western Africa sites, respectively). We considered lowering the AOD threshold so as to include more cases but this would reduce confidence about the actual presence of dust.

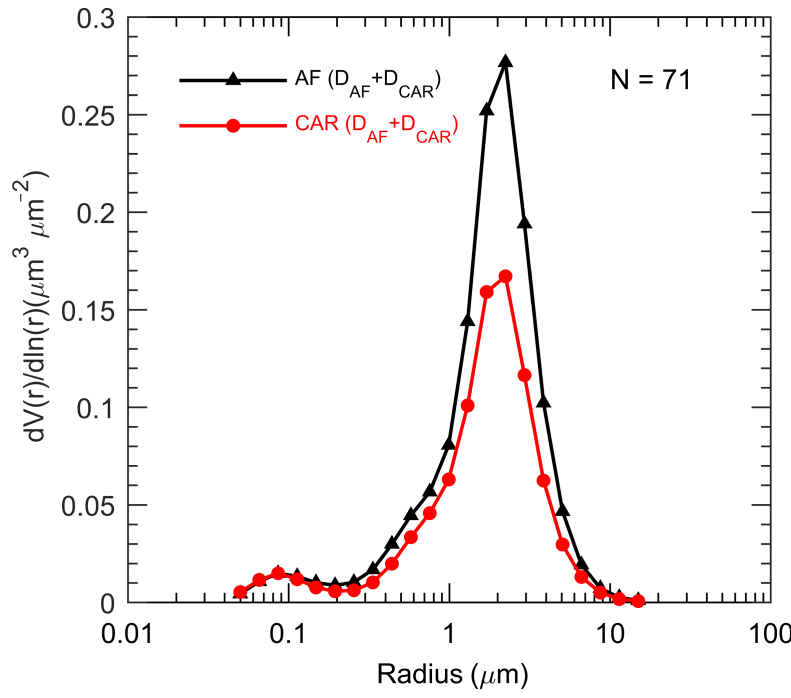

Figure 9. Volume particle size distribution, $\mathrm{d} V(r) / \mathrm{d} \ln (r)$, in the western Africa (AF) and the Caribbean (CAR) areas under desert dust conditions ( $D_{\mathrm{AF}}+D_{\mathrm{CAR}}$ case; see Sect. 2.2).

\subsection{Scatter plot of connected AOD data}

Once the connections have been detected, changes in AOD due to the long-range transport over the Atlantic Ocean are studied depending on the $\mathrm{AE}$ values. The results are shown in Fig. 8. The AOD ${ }_{C A R}$ has been plotted as a function of AOD at the western Africa sites $\left(\mathrm{AOD}_{\mathrm{AF}}\right)$.

The scatter plot in Fig. 8 shows that there is, as expected, a decrease in AOD in air masses transiting the Atlantic. The mean decrease of AOD between western Africa and Caribbean sites is 0.16 , a decrease of about $30 \%$ with respect to the values at Dakar and Cabo Verde. They are greatest for cases where AOD values are large $(\mathrm{AOD}>0.8)$ at the 


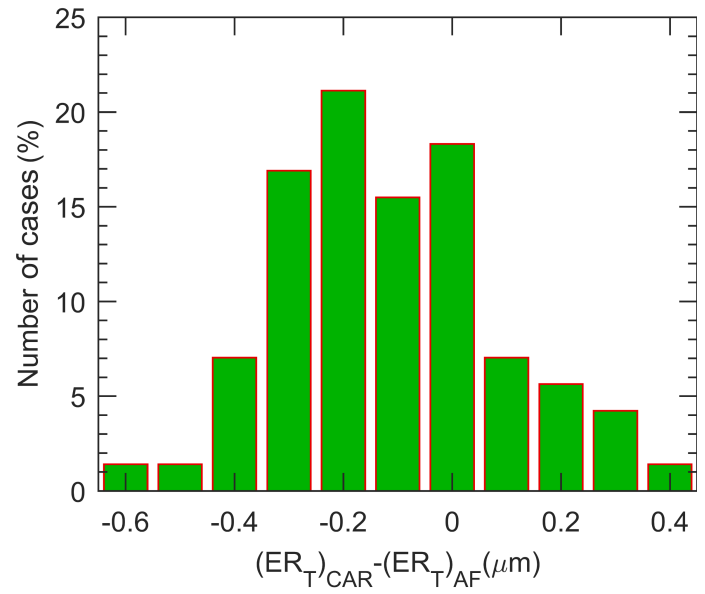

Figure 10. Histogram of the differences between the total effective radii in the western Africa region and in the Caribbean area for those cases with connected desert dust conditions in both areas $\left(D_{\mathrm{AF}}+D_{\mathrm{CAR}}\right.$ case $)$.

western Africa sites, with decreases up to $70 \%$. In the interval $0.5<\mathrm{AOD}<0.8$ the decreases are in the range of about $28-45 \%$, while those in the interval $0.2<\mathrm{AOD}<0.5$ are in the range $11-27 \%$. These percentages based on long-term and ground-based data are a first approach to assess the estimations done by studies dealing with satellite data. For instance, Yu et al. (2015) have reported, in a latitudinal belt of $10^{\circ} \mathrm{S}-30^{\circ} \mathrm{N}$, a loss of $70 \%( \pm 45-70 \%)$ of the dust amount (in $\mathrm{Tg}^{-1}$ ) between western Africa (at $15^{\circ} \mathrm{W}$ ) and the end of the Caribbean sites (at $75^{\circ} \mathrm{W}$ ). Hence, our estimations are in line with these findings considering that the measured variable and studied area are not identical.

The cases with low AE values are those cases with a wider variability in AOD difference. In addition, there are some cases in which AOD is larger at the Caribbean sites. There could be different reasons which explain this effect: inhomogeneity of the dust layer, addition of other aerosol particles at the Caribbean sites, temporal gaps in the instantaneous measurements that cause non-representative daily averages, and cloud contamination not detected by the cloud-screening algorithm, for example.

\subsection{Aerosol microphysical properties for African-Caribbean Sea connections}

In this section we focus on the key aerosol microphysical properties for those cases where we found a link between the western Africa and Caribbean sites. Figure 9 shows the average VPSD for the case analyzed before: dust conditions in both areas $\left(D_{\mathrm{AF}}+D_{\mathrm{CAR}}\right)$. The main characteristics of the VPSD curve for this collection of data in the western Africa sites are the same as described in detail in Sect. 4. The finemode volume fraction (obtained as the ratio $\mathrm{VC}_{\mathrm{F}} / \mathrm{VC}_{\mathrm{T}}$ ) is on average 0.077 .

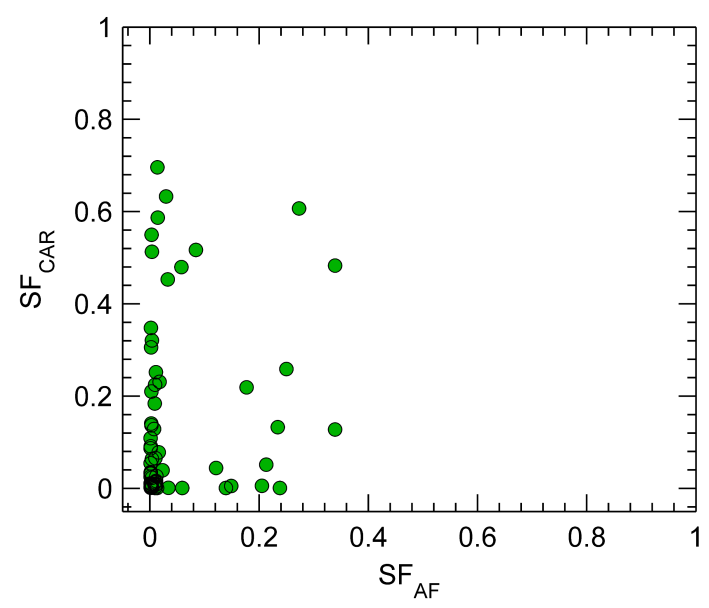

Figure 11. Sphericity fraction values in the western Africa region and in the Caribbean area for those cases with desert dust in both areas $\left(D_{\mathrm{AF}}+D_{\mathrm{CAR}}\right.$ case; see Sect. 2.2).

The VPSD at the Caribbean sites for the $D_{\mathrm{AF}}+D_{\mathrm{CAR}}$ case is similar to that at the western Africa sites: average coarse-mode volume concentration of $0.22 \mu \mathrm{m}^{3} \mu \mathrm{m}^{-2}$, maximum peak of about $2 \mu \mathrm{m}$ radius, and very low fine-mode concentration (average of $0.02 \mu \mathrm{m}^{3} \mu \mathrm{m}^{-2}$ peaking at $0.086 \mu \mathrm{m}$, fine-mode volume fraction of 0.09 ). The coarse-mode volume concentration decreases from $0.34 \mu^{3} \mu \mathrm{m}^{-2}$ in western Africa to $0.22 \mu \mathrm{m}^{3} \mu \mathrm{m}^{-2}$ at the Caribbean sites. Hence, there is a loss of about $35 \%$ in the coarse-mode concentration between both areas caused by the long-range transport over the Atlantic Ocean.

To quantify the change in the mean aerosol size caused by the long-range transport, Fig. 10 shows the histogram of the differences between the effective radius of the total size distribution $\left(\mathrm{ER}_{\mathrm{T}}\right)$ in the two areas. On average, $\mathrm{ER}_{\mathrm{T}}$ shows values of 0.88 and $0.76 \mu \mathrm{m}$ in western Africa and Caribbean sites, respectively. Most of the differences in the $\mathrm{ER}_{\mathrm{T}}$ values are negative, thus indicating the size distribution in western Africa generally having larger particles than at the Caribbean sites. The differences in the effective radii are mostly confined (about $70 \%$ of the cases) between no change and a decrease in the effective radius of about $0.3 \mu \mathrm{m}$ between both areas. The maximum of occurrence is found for a decrease of about $0.2 \mu \mathrm{m}$. Positive differences ( $15 \%$ of the cases), meaning larger particle size at the Caribbean sites, could be attributed to the presence of other aerosol layers (e.g., sea salt) in the atmospheric column. Uncertainties of the inversion could also explain the positive differences.

The third microphysical property studied here is the fraction of spherical particles found in the inversion process. In the retrieval, particles are modeled both as spheres and spheroids, and the inversion finds which fraction of spherical and non-spherical particles better fits the observations (for details, see Dubovik at al., 2006). The results are presented in Fig. 11. This figure shows that at the western Africa sites 

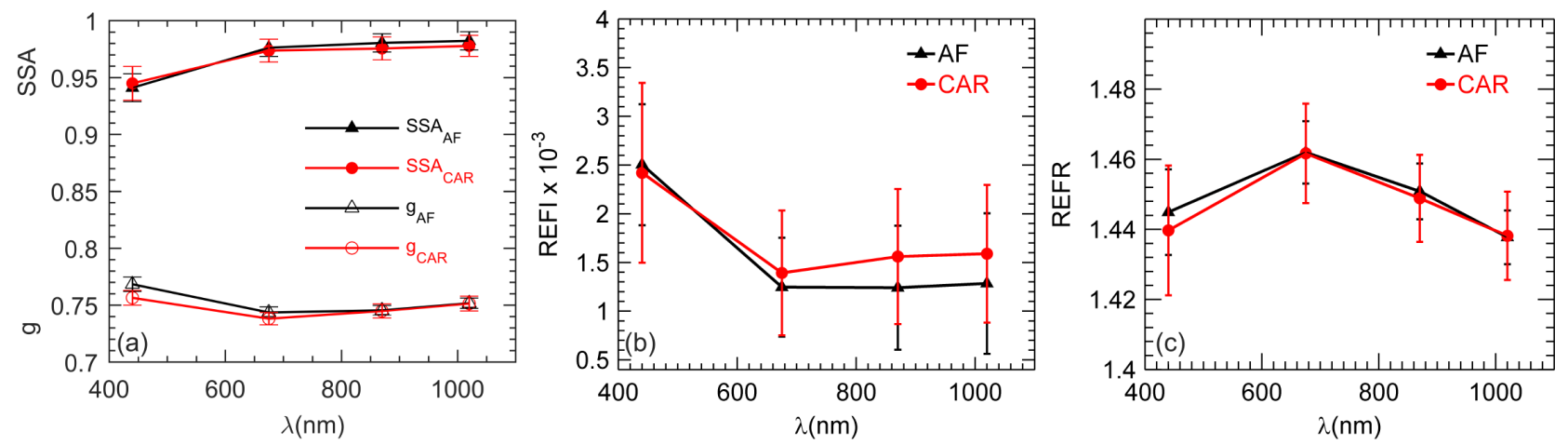

Figure 12. Average values of (a) single scattering albedo (SSA) and asymmetry parameter $(g)$, (b) imaginary part of the refractive index (REFI), and (c) real part of the refractive index (REFR) for those cases with desert dust in both the western Africa region (black lines) and Caribbean area (red lines; $D_{\mathrm{AF}}+D_{\mathrm{CAR}}$ case; see Sect. 2.2).

there is a large predominance of non-spherical particles, that is, $\mathrm{SF}<0.05$. Respectively, about 80 and $53 \%$ of the values at the western Africa and Caribbean sites were completely non-spherical. Overall, in 32 out of 71 cases $(45 \%)$ there is no change between both areas and the shape of the particles is predominantly non-spherical. Cases with sphericity fraction below 0.05 in western Africa sites display a wide variability in the observed fraction at the Caribbean sites, even achieving values of 0.7 . This increase could be explained by the mixture of mineral dust with other (spherical) aerosol particles, such as maritime aerosols. Note that we use column observations; therefore the mixture in this case does not mean that dust and other aerosol particles are necessarily in the same layer; they can be separated in different atmospheric layers. For instance, during the SALTRACE experiment the main four dust events recorded presented a vertical structure with up to three layers: the boundary layer, the entrainment or mixing layer, and the pure Saharan dust layer (Groß et al., 2015). Uncertainties of the inversion method can also be a reason for the high fraction of spherical particles. The in situ measurements at Barbados collect dust in the boundary layer (Prospero, 1999; Smirnov et al., 2000; Yu et al., 2014), so that dust is collected simultaneously with sea salt and other aerosol types (e.g., Ansmann et al., 2009; Toledano et al., 2011; Groß et al., 2011). There is a correlation between high in situ dust mass concentrations, high total aerosol optical depth, and low Ångström exponent (Groß et al., 2016). However the highest concentrations of dust are found in the elevated Saharan Air Layer (Yu et al., 2014), where there are no significant concentrations of sea salt aerosol (Savoie et al., 2002).

\subsection{Aerosol radiative properties for African-Caribbean Sea connections}

Figure 12 compares the main radiative properties (SSA, $g$, REFR, and REFI) at the Caribbean and western Africa sites to assess changes in optical properties that occur after long- range transport. SSA in Fig. 12a and REFI in Fig. 12c are the same in both areas within the limits of uncertainty. The SSA at Dakar and Cabo Verde increases with wavelength: from 0.94 at $440 \mathrm{~nm}$ up to 0.98 at 670,870 , and $1020 \mathrm{~nm}$. These figures are in line with previous studies in this area (Dubovik et al., 2002; Eck et al., 2010; Kim et al., 2011; Toledano et al., 2011; Giles et al., 2012, among others) and also with measurements at various Spanish and Mediterranean sites during desert dust outbreaks (e.g., Meloni et al., 2006; Cachorro et al., 2010; Valenzuela et al., 2012; Burgos et al., 2016). The SSA in dust events at the Caribbean sites is essentially identical to that at the western Africa sites. The same is true for REFI: 0.0025 at $440 \mathrm{~nm}$ and $0.001-0.0015$ in the interval $670-1020 \mathrm{~nm}$. The values in the visible and near infrared ranges are slightly larger than those reported by Dubovik et al. (2002) which were about 0.0007 ; their value at $440 \mathrm{~nm}$ is very similar to the value we present here. There is no significant change in the REFR either, as it is the mean real part of the refractive index in the African and Caribbean database, at about $1.45 \pm 0.01$. This value is slightly lower than that reported by Dubovik et al. (2002) which was about 1.48. Finally, the asymmetry factor $g$ at $440 \mathrm{~nm}$ decreases slightly from 0.77 in western Africa sites to 0.755 at the Caribbean sites. The $g$ values reported in this study are slightly larger than those reported by previous studies for desert dust in Africa (e.g., Dubovik et al., 2002). Overall, the intensive optical properties (both absorption and scattering quantities) do not change significantly in spite of the long-range transport.

\section{Conclusions}

The objective of this study was to characterize changes in aerosol physical-radiative properties that occur in dust-laden air masses that transit the Atlantic from Africa to the eastern Caribbean. To this end we compared AERONET sun photometer measurements and inversion products made over the period 1996-2014 at five island sites in the eastern Caribbean 
with those made at two sites in western Africa. Focusing first on the results observed from the two western Africa sites, we find that the dust properties are quite similar to those previously reported for Saharan dust in field experiments and previous studies using AERONET data.

We focused efforts on paired measurements made on the same dust outbreaks in a procedure that identified trajectories from the Caribbean island sites that back-tracked to one or both of the western Africa sites. We find that there is no substantial change in the intensive radiative properties in western Africa air masses after a journey of 5-7 days over a distance of $4000 \mathrm{~km}$. There is a decrease of about $30 \%$ in the coarse-mode concentration of the size distributions but the coarse-mode effective radius does not change. Non-spherical particles characteristic of dust are the predominant shape in both areas. In general there were no substantial changes in the spectral dependence of the absorbing and scattering properties of dust during transit.

Our findings that suggest uniformity in properties are similar to those reached in Bozlaker et al. (2017), who measured the concentrations and isotopic composition of a broad suite of elements in Barbados dust samples collected in 2013 and 2016. Although dust concentrations were highly variable, the elemental and isotopic abundances fell within a relatively narrow range compared to wide-ranging compositions reported for hypothesized dust sources in North Africa. In contrast the Barbados composition was very similar to that reported in the literature for samples collected at sites on the coast of western Africa on islands or ships close to the coast. These results suggest that during large dust events, the dust from different sources which may have different signatures becomes homogenized during transport from the interior of North Africa to the coast and that there is relatively little change in dust properties during transit of the Atlantic.

The results of our study and that of Bozlaker et al. (2017) suggest that the modeling of the radiative effects of dust over the Atlantic can be simplified in that it can be assumed that the radiative properties of dust are relatively uniform and unchanging during transport within the context of the range of properties discussed here.

Data availability. Backward trajectories analysis has been supported by air mass transport computation with the NOAA (National Oceanic and Atmospheric Administration) HYSPLIT (HYbrid Single-Particle Lagrangian Integrated Trajectory) model using GDAS meteorological data (Stein et al., 2015). AERONET sun photometer data are downloaded from the AERONET web page (Holben et al., 1998).

Competing interests. The authors declare that they have no conflict of interest.
Special issue statement. This article is part of the special issue "The Saharan Aerosol Long-range Transport and Aerosol-Cloudinteraction Experiment (SALTRACE; ACP/AMT inter-journal SI)". It is not associated with a conference.

Acknowledgements. The authors gratefully acknowledge the NASA AERONET program for the very valuable data used in this study. We thank Brent Holben (Barbados, La_Parguera), Didier Tanre (Capo_Verde, Dakar), and Olga Mayol-Bracero (Cape San Juan) for their effort in establishing and maintaining their sites. This work has received funding from the European Union's Horizon 2020 research and innovation programme under grant agreement no. 54109 (ACTRIS-2). The authors are grateful to Spanish MINECO for the financial support of the IJCI2014-19477 grant, PTA2014-09522-I grant, and POLARMOON project (ref. CTM2015-66742-R). We also thank "Consejería de Educación" of "Junta de Castilla y León" for supporting the GOA-AIRE project (ref. VA100P17). Prospero received support from NSF AGS-0962256 and NASA NNX12AP45G.

Edited by: Bernadett Weinzierl

Reviewed by: three anonymous referees

\section{References}

Ansmann, A., Baars, H., Tesche, M., Müller, D., Althausen, D., Engelmann, R., Pauliquevis, T., and Artaxo, P.: Dust and smoke transport from Africa to South America: Lidar profiling over Cape Verde and the Amazon rainforest, Geophys. Res. Lett., 36, L11802, https://doi.org/10.1029/2009GL037923, 2009.

Bozlaker, A., Prospero, J. M., Fraser, M. P., and Chellam, S.: Quantifying the contribution of long-range Saharan dust transport on particulate matter concentrations in Houston, Texas, using detailed elemental analysis, Environ. Sci. Technol., 47, 1017910187, https://doi.org/10.1021/es4015663, 2013.

Bozlaker, A., Prospero, J. M., Price, J., and Chellam, S.: Linking Barbados Mineral Dust Aerosols to North African Sources Using Elemental Composition and Radiogenic $\mathrm{Sr}, \mathrm{Nd}$, and $\mathrm{Pb}$ Isotope Signatures, J. Geophys. Res.-Atmos., 123, 1384-1400, https://doi.org/10.1002/2017JD027505, 2017.

Burgos, M. A., Mateos, D., Cachorro, C., Toledano, C., and de Frutos, A. M.: Aerosol properties of mineral dust and its mixtures in a regional background of north-central Iberian Peninsula, Sci. Total Environ., 572, 1005-1019, 2016.

Cachorro, V. E., Toledano, C., Antón, M., Berjón, A., de Frutos, A. M., Vilaplana, J. M., Arola, A., and Krotkov, N. A.: Comparison of UV irradiances from Aura/Ozone Monitoring Instrument (OMI) with Brewer measurements at El Arenosillo (Spain) - Part 2: Analysis of site aerosol influence, Atmos. Chem. Phys., 10, 11867-11880, https://doi.org/10.5194/acp-10-118672010, 2010.

Carlson, T. N. and Prospero, J. M.: The Large-Scale Movement of Saharan Air Outbreaks over the Northern Equatorial Atlantic, J. Appl. Meteorol., 11, 283-297, 1972.

Choobari, O. A., Zawar-Reza, P., and Sturman, A.: The global distribution of mineral dust and its impacts on the 
climate system: A review, Atmos. Res., 138, 152-165, https://doi.org/10.1016/j.atmosres.2013.11.007, 2014.

Chouza, F., Reitebuch, O., Benedetti, A., and Weinzierl, B.: Saharan dust long-range transport across the Atlantic studied by an airborne Doppler wind lidar and the MACC model, Atmos. Chem. Phys., 16, 11581-11600, https://doi.org/10.5194/acp-16-115812016, 2016.

Colarco, P., Toon O., and Holben B.: Saharan dust transport to the Caribbean during PRIDE: 1. Influence of dust sources and removal mechanisms on the timing and magnitude of downwind aerosol optical depth events from simulations of in situ and remote sensing observations, J. Geophys. Res., 108, 8589, https://doi.org/10.1029/2002JD002658, 2003.

DeMott, P. J., Prenni, A. J., Liu, X., Kreidenweis, S. M., Petters, M. D., Twohy, C. H., Richardson, M. S., Eidhammer, T., and Rogers, D. C.: Predicting global atmospheric ice nuclei distributions and their impacts on climate, P. Natl. Acad. Sci. USA, 107, 1121711222, https://doi.org/10.1073/pnas.0910818107, 2010.

Derimian, Y., Leon, J.-F., Dubovik, O., Chiapello, I., Tanré, D.,Sinyuk, A., Auriol, F., Podvin, T., Brogniez, G., and Holben, B.: Radiative properties of aerosol mixture observed during the dry season 2006 over M'Bour, Senegal (African Monsoon Miltidisciplinary Analysis campaign), J. Geophys. Res., 113, D00C09, https://doi.org/10.1029/2008JD009904, 2008.

Dubovik, O., Smirnov, A., Holben, B., King, M. D., Eck, T. F., Kaufman, Y. J., and Slutsker, I., and Eck, T. F.: Accuracy assessments of aerosol optical properties retrieved from Aerosol Robotic Network (AERONET) Sun and sky radiance measurements, J. Geophys. Res., 105, 9791-9806, 2000.

Dubovik, O., Holben, B., Eck, T. F., Smirnov, A., Kaufman, Y. J., King, M. D., Tanre, D., and Slutsker, I.: Variability of absorption and optical properties of key aerosol types observed in worldwide locations, J. Atmos. Sci., 59, 590-608, 2002.

Dubovik, O., Sinyuk, A., Lapyonok, T., Holben, B. N., Mishchenko, M., Yang, P., Eck, T. F., Volten, H., Munoz, O., Veihelmann, B., van der Zande, W. J., Leon, J. F., Sorokin, M., and Slutsker, I.: Application of spheroid models to account for aerosol particle nonsphericity in remote sensing of desert dust, J. Geophys. Res.-Atmos., 111, 2156-2202, https://doi.org/10.1029/2005JD006619, 2006.

Eck, T. F., Holben, B. N., Sinyuk, A., Pinker, R. T., Goloub, P., Chen, H,. Chatenet, B., Li, Z., Singh, R. P., Tripathi, S. N., Reid, J. S., Giles, D. M., Dubovik, O., O’Neill, N. T., Smirnov, A., Wang, P., and Xia, X.: Climatological aspects of the optical properties of fine/coarse mode aerosol mixtures, J. Geophys. Res., 115, D19205, https://doi.org/10.1029/2010JD014002, 2010.

García, M. I., Rodríguez, S., and Alastuey, A.: Impact of North America on the aerosol composition in the North Atlantic free troposphere, Atmos. Chem. Phys., 17, 7387-7404, 10.5194/ acp-17-7387-2017, 2017.

Giles, D. M., Holben, B. N., Eck, T. F., Sinyuk, A., Smirnov, A., Slutsker, I., Dickerson, R. R., Thompson, A. M., and Schafer, J. S.: An analysis of AERONET aerosol absorption properties and classifications representative of aerosol source regions, J. Geophys. Res., 117, D17203, https://doi.org/10.1029/2012JD018127, 2012.

Groß, S., Tesche, M., Freudenthaler, V., Toledano, C., Wiegner, M., Ansmann, A., Althausen, D., and Seefeldner, M.: Characterization of Saharan dust, marine aerosols and mixtures of biomass- burning aerosols and dust by means of multi-wavelength depolarization and Raman lidar measurements during SAMUM 2, Tellus B, 63, 706-724, https://doi.org/10.1111/j.16000889.2011.00556.x, 2011.

Groß, S., Freudenthaler, V., Schepanski, K., Toledano, C., Schäfler, A., Ansmann, A., and Weinzierl, B.: Optical properties of long-range transported Saharan dust over Barbados as measured by dual-wavelength depolarization Raman lidar measurements, Atmos. Chem. Phys., 15, 11067-11080, https://doi.org/10.5194/acp-15-11067-2015, 2015.

Groß, S., Gasteiger, J., Freudenthaler, V., Müller, T., Sauer, D., Toledano, C., and Ansmann, A.: Saharan dust contribution to the Caribbean summertime boundary layer - a lidar study during SALTRACE, Atmos. Chem. Phys., 16, 11535-11546, https://doi.org/10.5194/acp-16-11535-2016, 2016.

Guirado, C., Cuevas, E., Cachorro, V. E., Toledano, C., AlonsoPérez, S., Bustos, J. J., Basart, S., Romero, P. M., Camino, C., Mimouni, M. Zeudmi, L. Goloub, P., Baldasano, J. M., and de Frutos, A. M.: Aerosol characterization at the Saharan AERONET site Tamanrasset, Atmos. Chem. Phys., 14, 1175311773, https://doi.org/10.5194/acp-14-11753-2014, 2014.

Haywood, J., Pelon, J., Formenti, P., Bharmal, N., Brooks, M., Capes, G., Chazette, P., Chou, C., Christopher, S., Coe, H., Cuesta, J., Derimian,Y., Desboeufs, K., Greed, G., Harrison, M., Heese, B., Highwood, E. J., Johnson, B., Mallet, M., Marticorena, B., Marsham, J., Milton, S., Myhre, G., Osborne, S. R., Parker, D. J., Rajot, J.-L., Schulz, M., Slingo, A., Tanré, D., and Tulet, P.: Overview of the dust and biomass burning experiment and African monsoon multidisciplinary analysis special observing period-0, J. Geophys. Res., 113, D00C11, https://doi.org/10.1029/2008JD010077, 2008.

Holben, B. N., Eck,, Slutsker, I., Tanré, D., Buis, J. P., Setzer, A., Vermote, E., and Smirnov, A.: AERONET - A federated instrument network and data archive for aerosol characterization, Remote. Sens. Environ., 66, 1-16, https://doi.org/10.1016/S00344257(98)00031-5, 1998.

Horowitz, H. M., Garland, R. M., Thatcher, M., Landman, W. A., Dedekind, Z., van der Merwe, J., and Engelbrecht, F. A.: Evaluation of climate model aerosol seasonal and spatial variability over Africa using AERONET, Atmos. Chem. Phys., 17, 1399914023, https://doi.org/10.5194/acp-17-13999-2017, 2017.

Huneeus, N., Schulz, M., Balkanski, Y., Griesfeller, J., Prospero, J., Kinne, S., Bauer, S., Boucher, O., Chin, M., Dentener, F., Diehl, T., Easter, R., Fillmore, D., Ghan, S., Ginoux, P., Grini, A., Horowitz, L., Koch, D., Krol, M. C., Landing, W., Liu, X., Mahowald, N., Miller, R., Morcrette, J.-J., Myhre, G., Penner, J., Perlwitz, J., Stier, P., Takemura, T., and Zender, C. S.: Global dust model intercomparison in AeroCom phase I, Atmos. Chem. Phys., 11, 7781-7816, https://doi.org/10.5194/acp11-7781-2011, 2011.

Jickells, T.D., An, Z. S., Andersen, K. K., Baker, A. R., Bergametti, C., Brooks, N., and Cao, J. J., Boyd, P., W. Duce, R. A., Hunter, K. A., Kawahata, H., Kubilay, N., LaRoche, J., Liss, P. S., Mahowald, N., Prospero, J. M., Ridgwell, A. J., Tegen, I., and Torres, R.: Global Iron Connections Between Desert Dust, Ocean Biogeochemistry, and Climate, Science, 308, 6771, https://doi.org/10.1126/science.1105959, 2005.

Kalnay, E., Kanamitsu, M., Kistler, R., Collins, W., Deaven, D., Gandin, L., Iredell, M., Saha, S., White, G., Woollen, J., Zhu, Y., 
Chelliah, M., Ebisuzaki, W., Higgins, W., Janowiak, J., Mo, K.C., Ropelewski, C,. Wang, J., Leetmaa, A., Reynolds, R., Jenne, R., and Joseph, D.: The NCEP/NCAR 40-year reanalysis project, B. Am. Meteorol. Soc., 77, 437-470, 1996.

Karydis, V. A., Tsimpidi, A. P., Bacer, S., Pozzer, A., Nenes, A., Lelieveld, J.: Global impact of mineral dust on cloud droplet number concentration, Atmos. Chem. Phys., 17, 5601-5621, https://doi.org/10.5194/acp-17-5601-2017, 2017.

Kaufman, Y. J., Koren, I., Remer, L. A., Tanré, D., Ginoux, P., and Fan, S.: Dust transport and deposition observed from the Terra-Moderate Resolution Imaging Spectroradiometer (MODIS) spacecraft over the Atlantic Ocean, J. Geophys. Res., 110, D10S12, https://doi.org/10.1029/2003JD004436, 2005.

Kim, D., Chin, M., Yu, H., Eck, T. F., Sinyuk, A., Smirnov, A., and Holben, B. N.: Dust optical properties over North Africa and Arabian Peninsula derived from the AERONET dataset, Atmos. Chem. Phys., 11, 10733-10741, https://doi.org/10.5194/acp-1110733-2011, 2011

Knippertz, P. and Stuut, J.-B. W.: Chapter 1 Introduction, in: Mineral Dust: A Key Player in the Earth System, edited by: Knippertz, P. and Stuut, J.-B. W., Springer, New York, 1-14, https://doi.org/10.1007/978-94-017-8978-3, 2014.

Leon, J. F., Derimian, Y., Chiapello, I., Tanre, D., Podvin, T., Chatenet, B., Diallo, A., and Deroo, C.: Aerosol vertical distribution and optical properties over M'Bour $\left(16.96^{\circ} \mathrm{W} ; 14.39^{\circ} \mathrm{N}\right)$, Senegal from 2006 to 2008, Atmos. Chem. Phys., 9, 9249-9261, https://doi.org/10.5194/acp-9-9249-2009, 2009.

Mallet, M., Dubovik, O., Nabat, P., Dulac, F., Kahn, R., Sciare, J., Paronis, D., and Léon, J. F.: Absorption properties of Mediterranean aerosols obtained from multi-year ground-based remote sensing observations, Atmos. Chem. Phys., 13, 9195-9210, https://doi.org/10.5194/acp-13-9195-2013, 2013.

Maring, H., Savoie, D. L., Izaguirre, M. A., Custals, L., and Reid, J. S.: Mineral dust aerosol size distribution change during atmospheric transport, J. Geophys. Res., 108, 8592, https://doi.org/10.1029/2002JD002536, 2003.

Martet, M., Peuch, V. H., Laurent, B., and Marticorena, B.: Evaluation of long-range transport and deposition of desert dust with the CTM MOCAGE, Tellus B, 61, 446-463, https://doi.org/10.1111/j.1600-0889.2008.00413.x, 2009.

Mateos, D., Antón, M., Toledano, C., Cachorro, V. E., AladosArboledas, L., Sorribas, M., and Baldasano, J. M.: Aerosol radiative effects in the ultraviolet, visible, and near-infrared spectral ranges using long-term aerosol data series over the Iberian Peninsula, Atmos. Chem. Phys., 14, 13497-13514, https://doi.org/10.5194/acp-14-13497-2014, 2014.

Meloni, D., di Sarra, A., Pace, G., and Monteleone, F.: Aerosol optical properties at Lampedusa (Central Mediterranean). 2. Determination of single scattering albedo at two wavelengths for different aerosol types, Atmos. Chem. Phys., 6, 715-727, https://doi.org/10.5194/acp-6-715-2006, 2006.

Prats, N., Cachorro, V. E., Berjón, A., Toledano, C., and De Frutos, A. M.: Column-integrated aerosol microphysical properties from AERONET Sun photometer over southwestern Spain, Atmos. Chem. Phys., 11, 12535-12547, https://doi.org/10.5194/acp-1112535-2011, 2011.

Prospero, J. M.: Long-term measurements of the transport of African mineral dust to the southeastern United States: Impli- cations for regional air quality, J. Geophys. Res.-Atmos., 104, 15917-15927, 1999.

Prospero, J. M. and Mayol-Bracero O. L.: Understanding the transport and impact of African dust on the Caribbean Basin, B. Am. Meteorol. Soc., 94, 1329-1337, https://doi.org/10.1175/BAMSD-12-00142.1, 2013.

Prospero, J. M. and Peter J. L.: African Droughts and Dust Transport to the Caribbean: Climate Change Implications, Science, 302, 1024-1027, https://doi.org/10.1126/science.1089915, 2003.

Prospero, J. M., Collard, F. X., Molinié, J., and Jeannot, A.: Characterizing the annual cycle of African dust transport to the Caribbean Basin and South America and its impact on the environment and air quality, Global Biogeochem. Cy., 28, GB004802, https://doi.org/10.1002/2013GB004802, 2014.

Reid, J. S., Kinney, J. E., Westphal, D. L., Holben, B. N., Welton, E. J., Tsay, S.-C., Eleuterio, D. P., Campbell, J. R., Christopher, S. A., Colarco, P. R., Jonsson, H. H., Livingston, J. M., Maring, H. B., Meier, M. L., Pilewskie, P., Prospero, J. M., Reid, E. A., Remer, L. A., Russell, P. B., Savoie, D. L., Smirnov, A., and Tanré, D.: Analysis of measurements of Saharan dust by airborne and ground-based remote sensing methods during the Puerto Rico Dust Experiment (PRIDE), J. Geophys. Res., 108, 8586, https://doi.org/10.1029/2002JD002493, 2003.

Rodríguez, S., Cuevas, E., Prospero, J. M., Alastuey, A., Querol, X., López-Solano, J., García, M. I., and Alonso-Pérez, S.: Modulation of Saharan dust export by the North African dipole, Atmos. Chem. Phys., 15, 7471-7486, https://doi.org/10.5194/acp15-7471-2015, 2015.

Savoie, D. L., Arimoto, R., Keene, W. C., Prospera, J. M., Duce, R. A., and Galloway, J. N.: Marine biogenic and anthropogenic contributions to non-sea-salt sulfate in the marine boundary layer over the North Atlantic Ocean, J. Geophys. Res.-Atmos., 107, 4356, https://doi.org/10.1029/2001JD000970, 2002.

Smirnov, A., Holben, B. N., Savoie, D., Prospero, J. M., Kaufman, Y. J., Tanre, D., Eck, T. F., and Slutsker, I.: Relationship between column aerosol optical thickness and in situ ground based dust concentrations over Barbados, Geophys. Res. Lett., 27, 16431646, 2000.

Stein, A. F., Draxler, R. R, Rolph, G. D., Stunder, B. J. B., Cohen, M. D., and Ngan, F.: NOAA's HYSPLIT atmospheric transport and dispersion modeling system, B. Am. Meteorol. Soc., 96, 2059-2077, 2015.

Tegen, I., Schepanski, K., and Heinold, B.: Comparing two years of Saharan dust source activation obtained by regional modelling and satellite observations, Atmos. Chem. Phys., 13, 2381-2390, https://doi.org/10.5194/acp-13-2381-2013, 2013.

Toledano, C., Wiegner, M., Groß, S., Freudenthaler, V., Gasteiger, J., Müller, D., Müller, T., Schladitz, A., Weinzierl, B., Torres, B., and O'Neill, N. T.: Optical properties of aerosol mixtures derived from sun-sky radiometry during SAMUM-2, Tellus B, 63, 635648, 2011.

Valenzuela, A., Olmo, F. J., Lyamani, H., Antón, M., Quirantes, A., and Alados-Arboledas, L.: Aerosol radiative forcing during African desert dust events (2005-2010) over Southeastern Spain, Atmos. Chem. Phys., 12, 10331-10351, https://doi.org/10.5194/acp-12-10331-2012, 2012.

Valle-Díaz, C. J., Torres-Delgado E., Colón-Santos S. M., Lee T., Collett Jr. J. L., McDowell W. H., and Mayol-Bracero O. L.: Impact of long-range transported African dust on cloud 
water chemistry at a tropical montane cloud forest in northeastern Puerto Rico, Aerosol Air Qual. Res., 16, 653-664, https://doi.org/10.4209/aaqr.2015.05.0320, 2016.

Weinzierl, B., Ansmann, A., Prospero, J. M., Althausen, D., Benker, N., Chouza, F., Dollner, M., Farrell, D., Fomba, W. K., Freudenthaler, V., Gasteiger, J., Groß, S., Haarig, M., Heinold, B., Kandler, K., Kristensen, T. B., Mayol-Bracero, O. L., Müller, T., Reitebuch, O., Sauer, D., Schäfler, A., Schepanski, K., Spanu, A., Tegen, I., Toledano, C., and Walser, A.: The Saharan aerosol long-range transport and aerosol-cloud-interaction experiment: Overview and selected highlights, B. Am. Meteorol. Soc., 98, 1427-1451, 2017.

Yu, H., Chin M., Bian H., Yuan T., Prospero J. M., Omar A. H., Remer L. A., Winker D. M., Yang Y., Zhang Y., and Zhang Z.: Quantification of trans-Atlantic dust transport from seven-year (2007-2013) record of CALIPSO lidar measurements, Remote Sens. Environ., 159, 232-249, https://doi.org/10.1016/j.rse.2014.12.010, 2014.
Yu, H., Chin, M., Yuan, T., Bian, H., Remer, L. A., Prospero, J. M., Omar, A., Winker, D., Yang, Y., Zhang, Y., Zhang, Z., and Zhao, C.: The fertilizing role of African dust in the Amazon rainforest: A first multiyear assessment based on data from Cloud-Aerosol Lidar and Infrared Pathfinder Satellite Observations, Geophys. Res. Lett., 42, GL063040, https://doi.org/10.1002/2015GL063040, 2015.

Zamora, L. M., Prospero, J. M., Hansell, D. A., and Trapp, J. M.: Atmospheric P deposition to the subtropical North Atlantic: sources, properties, and relationship to $\mathrm{N}$ deposition, J. Geophys. Res.-Atmos., 118, 1546-1562, https://doi.org/10.1002/jgrd.50187, 2013. 